\title{
EXAMINATION OF CAUSES OF GROWTH DEPENSATION IN JUVENILE, MONOSEX NILE TILAPIA (Oreochromius niloticus)
}

\author{
Mohamed M. Said ${ }^{1}$ and Manaa, Eman A. ${ }^{2}$ \\ 1- Department of Aquaculture, Faculty of Fish Resources, Suez University, Suez, Egypt, \\ msaid226@yahoo.com, 2- Department of Animal Wealth Development, Faulty of Veterinary Medicine, \\ Banha University, El-Kalyobia, Egypt
}

\section{SUMMARY}

Six hundred Nile tilapia Oreochromius niloticus monosex fingerlings (mean 0.98g \pm standard error 0.02) were stocked (50 fingerlings $/ \mathrm{m}^{2}$ ) into 6 different hapas to constitute two experimental groups control group $(C)$ and base group (B). After 4 weeks the larger 20 fish in each hapa in the base group were designated to establish the experimental group $\left(I_{1}\right)$. After another 4 weeks the 15 larger fish in each hapa in the base group were also designated to form another experimental group $\left(I_{2}\right)$. All formed experimental groups were reared for another further 8 weeks. The coefficient of variation (C.V.\%) showed a notable increase at the end of the experiment for all experimental groups including (C) from 22.1 to $39.2 \%$; (B) from 21.5 to $26.2 \%$; ( $I_{1}$ ) from 18.4 to $27.3 \%$; and similarly $\left(I_{2}\right)$ from 15.6 to $25.5 \%$. Final coefficient of variation (C.V. \%) in the control group (C) $39.2 \%$ was significantly higher $(p<0$.001) than those of all another experimental groups. Size distributions for all experimental groups also typically skewed positively towards the larger fish with time. The coefficient of skewness increased from $-0.3,-0.21,0.7$, and 0.56 for $C, B, I_{1}$, and $I_{2}$, respectively to $1.84,0.7,1.15$, and 1.22 at the end of the experiment. Specific growth rates\% of the base group (B) were significantly $(p<0.001)$ higher than those of all other experimental groups after larger fish designation indicating an enhancement in the growth of the remaining individuals. The final body weight of $I_{1}$ and $I_{2}(15.91 \& 16.39 \mathrm{~g}$., respectively) were significantly $(p<0.001)$ higher than those of $C$ and $B$ groups $(12.88 \& 12.89$ g., respectively). Growth hormone receptor (GHR1) mRNA level was highly up regulated (5 folds) and Insulin growth factor-I (IGF-I) $m R N A$ level was lowly down regulated (0.76) in the liver of secondary isolated lager fish $\left(I_{2}\right)$ than those of the subordinate individuals remaining in the base group (B). The results of the current study led to suggest that repeated isolation of the larger fish from the rearing unit may help on reducing the final size variation and increasing the probability of fast growth for more individuals. The level of GHR1 mRNA was highly depending on the relative position in the hierarchal structure within the same rearing unit.

Keywords: Tilapia juvenile, growth depensation, size distribution, social interactions, gene expression

\section{INTRODUCTION}

Growth dispensation explained as few individuals grow to be large while the vast majority remains small, such phenomenon was reported in several animal species (Ra'rnan and Cohen, 1984 and Potthoff and Christman, 2006). Growth inconsistency is a common feature in numerous cultured fish especially during the early live stages (Assaf Barki et al., 2000; Michael and Lee, 2003; Corrêa et al., 2003; and Potthoff and Christman, 2006). Practically, the lack of uniformity and asymmetry in growth has considerable effect in commercial cultured fish. It is obviously profitable to produce uniform sized fish (Kelly and Heikes, 2013). Generally, a superior aquaculture system would be the one where the probability of fast growth is realized to all individuals. In order to reduce this variation it is essential to investigate the phenomenon, to grasp the factors that may influence it, and subsequently to determine how growth can be promoted and variation can be reduced, (Jobling and Baardvik, 1994 and Goldan et al., 1997, 1998). Different factors may results in growth depensation. Growth dissimilarities may results from genetic potential discrepancies in growth rate (Kinghorn, 1983). In this respect, Perez-
Sanchez and Bail (1999) suggested that the growth hormone receptor (GHR1) mRNA and Insulin growth factor-I (IGF-I) mRNA axis could be used as markers of growth performance and nutritional status in aquaculture. On the other hand some other factors e.g. stocking practices, environmental effects and social interactions may also results on such growth nonconformity (Michael and Lee, 2003 and Potthoff and Christman, 2006). As for Tilapia which represents the major cultured fish in the Egyptian aquaculture (GAFRD, 2014), some previous studies investigate several growth depenstion aspects like the social stress related to growth variation (Volpato and Fernandes 1994); Tilapia social behavior (Sudhindra, 1997); mechanism of growth variation (Volpato et al., 1998); effect of dominance relationship on cortisol level and other metabolic parameters (Corrêa et al., 2003), and the effect of stocking density and the effect of initial weight variation on size variation (Barbosoa et al., 2006).

The aim of this study was to investigate growth depensation in monosex Nile Tilapia juvenile through: 1) twice isolation of larger fish from a base population to explore the social component of growth depensation 2) gene expression comparison between 
the superior grown individuals and subordinates to examine the genetic component of growth depensation. Understanding of such growth variation sources could help in subsequent optimization of stocking practices, selection procedures, and avoiding the probable negative consequences.

\section{MATERIALS AND METHODS}

\section{Experimental design}

The experiment was lasted from May to October 2015 at a private tilapia hatchery in San-El-Hagar, Sharkia, Egypt. Six hundred Nile tilapia Oreochromius niloticus monosex juvenile (mean weight $0.98 \mathrm{~g} \pm$ standard error 0.02 ) were stocked with a density of 50 fish $/ \mathrm{m}^{2}$ into six hapas of total area $2 \mathrm{~m}^{2}$ to form two experimental groups with three replicates control group (C) and the base group (B). After 4 weeks all fish were weighted individually and the larger 20 fish from each hapa in the base group (B) were identified, isolated, and transferred into 3 another hapas of total area $0.5 \mathrm{~m}^{2}$ to consist the experimental group $\left(\mathrm{I}_{1}\right)$. After such isolation the stocking density in both $\mathrm{B} \& \mathrm{I}_{1}$ will be 40 fish $/ \mathrm{m}^{2}$. At the same time the stocking density in the control group (C) was also equalized to $40 \mathrm{fish} / \mathrm{m}^{2}$ with culling 20 fish per each hapa. After another 4 weeks all fish were weighed individually and the larger 15 fish from each hapa in the base group (B) were identified, isolated, and transferred into another three hapas of total area $0.5 \mathrm{~m}^{2}$ (stocking density 30 fish / $\mathrm{m}^{2}$ ), those secondary isolated larger fish formed the experimental group $\mathrm{I}_{2}$. At the same time the stocking density in $\mathrm{C}, \mathrm{B}$ and $\mathrm{I}_{1}$ was modified to be also 30 fish $/ \mathrm{m}^{2}$. After each culling process the weight and the size distribution were maintained similar to the original bulk population of each group in terms of mean weight and the coefficient of variation C.V. \%. All formed experimental groups were reared for another further 8 weeks rearing period.

\section{Fish management:}

All hapas were kept into $2000 \mathrm{~m}^{2}$ earthen pond. Water temperature ranged between 23 and $30^{\circ} \mathrm{C}, \mathrm{pH}$ value ranged between 7.2-7.9, and water salinity ranged between $2500-2850 \mathrm{mg} / \mathrm{L}$. Fish were fed at $8 \%$ ( 8 weeks) and $5 \%$ ( 8 weeks) of their body weight with $1 \mathrm{~mm}$ pellets commercial diet $(35 \%$ crude protein).

\section{Considered traits}

The specific growth rate (SGR\%) for each hapa was calculated as: $\mathrm{SGR}=100 \times(\ln W \mathrm{f}-\ln W \mathrm{i}) t^{-1}$, where $W \mathrm{f}$ is the final weight, $W_{1}$ is the initial weight in grams, and $t$ is the time in days (Hopkins, 1992). Fish were observed for any mortality during the experimental period and almost no mortalities were observed. The size variation was evaluated using the coefficient of variation and the coefficient of skewness. Coefficient of variation calculated as (C.V. $\%)=($ standard deviation /mean) X 100). Coefficient of skewness calculated as skew $=\{\mathrm{n} /((\mathrm{n}-1)(\mathrm{n}-2))\}$ $\mathrm{X} \sum\left\{\left(\mathrm{x}_{\mathrm{i}}-\mathrm{X}\right) / \text { standard deviation }\right\}^{3}$. Variability for weight of individual fish within each hapa was compared among experimental groups.

\section{Statistical analysis:}

Data were statistically analyzed using (IBM SPSS, 2013) according to the following model: $\mathrm{Y}_{\mathrm{ijk}}=$ $\mu+\mathrm{T}_{\mathrm{i}}+\mathrm{e}_{\mathrm{ij}}$, where, $\mu$ is the overall least square mean, $\mathrm{T}_{\mathrm{i}}$ is the fixed effect of experimental groups $(\mathrm{i}=1$; $\ldots 4)$, and $\mathrm{e}_{\mathrm{ij}}$ is random error ( NID; $\left.0 ; \sigma_{\mathrm{e}}\right)$. Least Squares Means were tested for significant differences using Duncan's Multiple Range Test (Duncun, 1955).

\section{Gene expression for the study:}

Gene expression study was carried out at Central Laboratory, Faculty of Veterinary Medicine, Benha University, Egypt. In order to investigate the prober genetic component of growth depensation, Liver samples were dissected from $\mathrm{I}_{2}$ (secondary isolated larger fish) and the smallest subordinate individuals which remaining in $\mathrm{B}$ after twice removing of larger fish. Liver samples were frozen at $-80^{\circ} \mathrm{C}$ immediately until use.

\section{Total RNA Extraction and Complementary Deoxyribonucleic Acid (cDNA) Synthesis:}

Total RNA was extracted from the frozen liver tissues using RNeasy® Mini kit (Qiagen) following the manufacturer's protocol. RNA quantity and quality were determined by using spectrostarNano drop. Single stranded cDNA was synthesized from $1000 \mathrm{ng}$ of total RNA according to manufacturer's protocol of High Capacity cDNA Reverse Transcription Kits (Applied Bio systems). Cycling conditions were: $25^{\circ} \mathrm{C}$ for $10 \mathrm{~min}, 37^{\circ} \mathrm{C}$ for $120 \mathrm{~min}$ and $85^{\circ} \mathrm{C}$ for $5 \mathrm{~min}$. Then total RNA and cDNA samples were stored at $-80^{\circ} \mathrm{C}$ until use.

\section{Primer Design:}

Primers used in this study (Table 1) were created for IGF-I and GHR1 genes and designed using the software GenScript Online PCR Primers Designs Tool. In this study B-actin gene is used as a reference gene (Davidson et al., 2003 and Bzhao et al., 2009).

Table 1. List of Primers used in this work

\begin{tabular}{|c|c|c|c|}
\hline Gene & Primer & Amplicon (bp) & Genbank (ID) \\
\hline B-actin & $\begin{array}{l}\text { F: GCCTCTCTGTCCACCTTCCA } \\
\text { R: GGGCCGGACCCATCGTACT }\end{array}$ & 62 & NM005159.4 \\
\hline IGF-I & $\begin{array}{l}\text { F: GTTTGTCTGTGGAGAGCGAGG } \\
\text { R: GAAGCAGCACTCGTCCACG }\end{array}$ & 97 & Y10830.1 \\
\hline GHR1 & $\begin{array}{l}\text { F: CAGACTTCTACGCTCAGGTC } \\
\text { R: CTGGATTCTGAGTTGCTGTC }\end{array}$ & 80 & AY973232.1 \\
\hline
\end{tabular}

F: Forward primer; R: Reverse primer 
Quantitative Real Time PCR (qRT-PCR):

PCR reactions for each gene were carried out for each analyzed sample. Each PCR reaction consisted of $1 \mu \mathrm{l}$ of $1 \mu \mathrm{g} / \mu \mathrm{l}$ cDNA, $10 \mu \mathrm{l}$ SYBR Green PCR Master Mix (QuantiTect SYBR Green PCR Kit, Qiagen), $1 \mu \mathrm{M}$ of each forward and reverse primer and nuclease free water to a final volume of $20 \mu \mathrm{l}$. Reactions were then analyzed on an Applied Biosystem 7500 Fast Real time PCR Detection system (Applied Bio systems) under the following conditions: $95^{\circ} \mathrm{C}$ for 10 minutes (holding stage) and 40 cycles of $95^{\circ} \mathrm{C}$ for 15 seconds (denaturation stage) followed by $60^{\circ} \mathrm{C}$ for 1 minute (annealing and extension stage). The amount of change in gene expression was calculated from the obtained cycle threshold (CT) values provided from real-time PCR instrumentation using the 2- $\Delta \Delta \mathrm{CT}$ calculation (Livak and Schmittgen, 2001) where $\Delta \mathrm{CT}$ indicates the CT changes in target gene in comparison with the reference gene.

\section{RESULTS AND DISCUSSION}

\section{Growth variation:}

Size variability may expressed as changes in cube root of the variances (Magnuson, 1962), the shape of size-frequency distributions (Chambers et al., 1988), the standard deviation (Koebele, 1985), the coefficient of variation (Ryer and Olla 1996), or the difference in coefficients of variation over time (Goldan et al., 1998), and coefficient of skewness (Assaf Barki et al., 2000). The results (Table 2 \& Fig.1) revealed that the coefficient of variation (C.V. $\%)$ increased with time for the experimental control group (C) from 22.1 to $39.2 \%$ at the end of the experiment. As for the base experimental group (B) from which we had twice removed the larger fish, the coefficient of variation C.V. \% also expressed a dramatically increase with time (Table 2 \& Fig.1). In spite that isolation of larger fish decreased the C.V. $\%$ to $18.3 \%$ after the first isolation and to $8.5 \%$ after the second one, the coefficient of variation $\%$ in $B$ reaches to $26.2 \%$ at the end of the experiment. Regarding to the experimental groups $I_{1}$ and $I_{2}$ which formed from the isolated graded larger fish with relatively smaller coefficients of variation C.V. \% (18.4 \& 15.6\% respectively), those groups also showed a notable increase in the size variation at the end of the experiment (27.2 \& $25.5 \%$, respectively) (Table 2 \& Fig 1). Therefore, the present results led to conclude that there were sources that generate and maintain variation in monosex tilapia fingerlings size within the same rearing unit. The final coefficient of variation C.V. \% in the control group (C) $39.2 \%$ was significantly higher $(\mathrm{p} \leq 0.001)$ than those of all other experimental groups $\mathrm{B}, \mathrm{I}_{1}$, and $\mathrm{I}_{2}$ which indicate that isolating of the larger fish helps on decreasing the final size variation.

Table 2. Growth and growth variability parameters of monosex Nile Tilapia fingerlings reared as four experimental groups $C$ : control group; B: base population from which larger fish were removed after $4 \&$ 8 weeks; I1: consisted from first isolated larger fish; and I2: consisted from secondary isolated larger fish

\begin{tabular}{|c|c|c|c|c|c|c|c|c|}
\hline $\begin{array}{l}\text { Experimental } \\
\text { Period }\end{array}$ & Group/N & $\begin{array}{l}\text { Initial } \\
\text { weight(g) }\end{array}$ & $\begin{array}{l}\text { Final } \\
\text { weight(g) }\end{array}$ & SGR\% & $\begin{array}{l}\text { Initial } \\
\text { c.v. } \%\end{array}$ & $\begin{array}{l}\text { Final } \\
\text { c.v.\% }\end{array}$ & $\begin{array}{l}\text { Initial } \\
\text { skewness }\end{array}$ & $\begin{array}{l}\text { Final } \\
\text { skewness }\end{array}$ \\
\hline \multirow[t]{2}{*}{ I:0-4 weeks } & C /100 & $0.98^{\mathrm{a}}$ & $4.68^{a}$ & $5.58^{\mathrm{a}}$ & $22.1^{\mathrm{a}}$ & $28.5^{\mathrm{b}}$ & $-0.3^{\mathrm{a}}$ & $1.25^{\mathrm{a}}$ \\
\hline & B /100 & $0.97^{\mathrm{a}}$ & $4.56^{\mathrm{a}}$ & $5.53^{\mathrm{a}}$ & $21.5^{\mathrm{a}}$ & $25.7^{\mathrm{a}}$ & $-0.21^{\mathrm{a}}$ & $1.4^{\mathrm{a}}$ \\
\hline \multirow[t]{3}{*}{ II:4-8 weeks } & C /80 & $4.68^{b}$ & $7.40^{\mathrm{b}}$ & $1.64^{\mathrm{b}}$ & $28.5^{\mathrm{a}}$ & $34.7^{\mathrm{a}}$ & $1.25^{\mathrm{a}}$ & $1.56^{\mathrm{a}}$ \\
\hline & B $/ 80$ & $3.4 b^{c}$ & $7.52^{\mathrm{b}}$ & $2.84^{\mathrm{a}}$ & $18.3^{\mathrm{b}}$ & $24^{\mathrm{b}}$ & $-0.05^{\mathrm{c}}$ & $1.21^{\mathrm{b}}$ \\
\hline & $\mathbf{I}_{1 / 2} 20$ & $7.06^{\mathrm{a}}$ & $10.34^{\mathrm{a}}$ & $1.35^{\mathrm{c}}$ & $18.4^{\mathrm{b}}$ & $22.3^{\mathrm{b}}$ & $0.42^{\mathrm{b}}$ & $0.7^{\mathrm{c}}$ \\
\hline \multirow{4}{*}{$\begin{array}{l}\text { III:8-12 } \\
\text { weeks }\end{array}$} & $\mathrm{C} / 60$ & $7.40^{\mathrm{b}}$ & $10.89^{b}$ & $1.38^{\mathrm{b}}$ & $34.7^{\mathrm{a}}$ & $37.9^{\mathrm{a}}$ & $1.56^{\mathrm{a}}$ & $1.58^{\mathrm{a}}$ \\
\hline & B $/ 60$ & $6.78^{\mathrm{b}}$ & $10.55^{\mathrm{b}}$ & $1.58^{\mathrm{a}}$ & $8.5^{\mathrm{d}}$ & $23.3^{\mathrm{b}}$ & $-0.08^{\mathrm{d}}$ & $0.36^{\mathrm{c}}$ \\
\hline & $\mathbf{I}_{1} / 15$ & $10.34^{\mathrm{a}}$ & $13.53^{\mathrm{a}}$ & $0.96^{\mathrm{c}}$ & $22.3^{b}$ & $23.5^{\mathrm{b}}$ & $0.7^{\mathrm{b}}$ & $1.05^{\mathrm{b}}$ \\
\hline & $\mathbf{I}_{\mathbf{2}} / 15$ & $10.54^{\mathrm{a}}$ & $14.05^{\mathrm{a}}$ & $1.03^{\mathrm{c}}$ & $15.6^{\mathrm{c}}$ & $21.1^{\mathrm{b}}$ & $0.56^{\mathrm{c}}$ & $1.09^{\mathrm{b}}$ \\
\hline \multirow{4}{*}{$\begin{array}{l}\text { IV:12-16 } \\
\text { weeks }\end{array}$} & $\mathrm{C} / 60$ & $10.89^{b}$ & $12.88^{\mathrm{b}}$ & $0.60^{b}$ & $37.9^{\mathrm{a}}$ & $39.2^{\mathrm{a}}$ & $1.58^{\mathrm{a}}$ & $1.84^{\mathrm{a}}$ \\
\hline & B $/ 60$ & $10.55^{\mathrm{b}}$ & $12.89^{\mathrm{b}}$ & $0.72^{\mathrm{a}}$ & $23.3^{\mathrm{b}}$ & $26.2^{\mathrm{b}}$ & $0.36^{\mathrm{c}}$ & $0.7^{\mathrm{c}}$ \\
\hline & $\mathbf{I}_{1} / 15$ & $13.53^{\mathrm{a}}$ & $15.91^{\mathrm{a}}$ & $0.58^{\mathrm{c}}$ & $23.5^{\mathrm{b}}$ & $27.2^{\mathrm{b}}$ & $1.05^{\mathrm{b}}$ & $1.15^{\mathrm{b}}$ \\
\hline & $\mathbf{I}_{2} / 15$ & $14.05^{\mathrm{a}}$ & $16.39^{\mathrm{a}}$ & $0.55^{\mathrm{c}}$ & $21.1^{b}$ & $25.5^{\mathrm{b}}$ & $1.09^{b}$ & $1.22^{\mathrm{b}}$ \\
\hline
\end{tabular}

C: control group; B: base population from which larger fish were removed after $4 \& 8$ weeks; $\mathrm{I}_{1}$ : consisted from first isolated larger fish; and $\mathrm{I}_{2}$ : consisted from secondary isolated larger fish. N: Number of fish in each hapa within each experimental group.

Values in the same column during each experimental period sharing the same letter are not significantly different from each other ( $\mathrm{p} \leq 0.05$ ). 


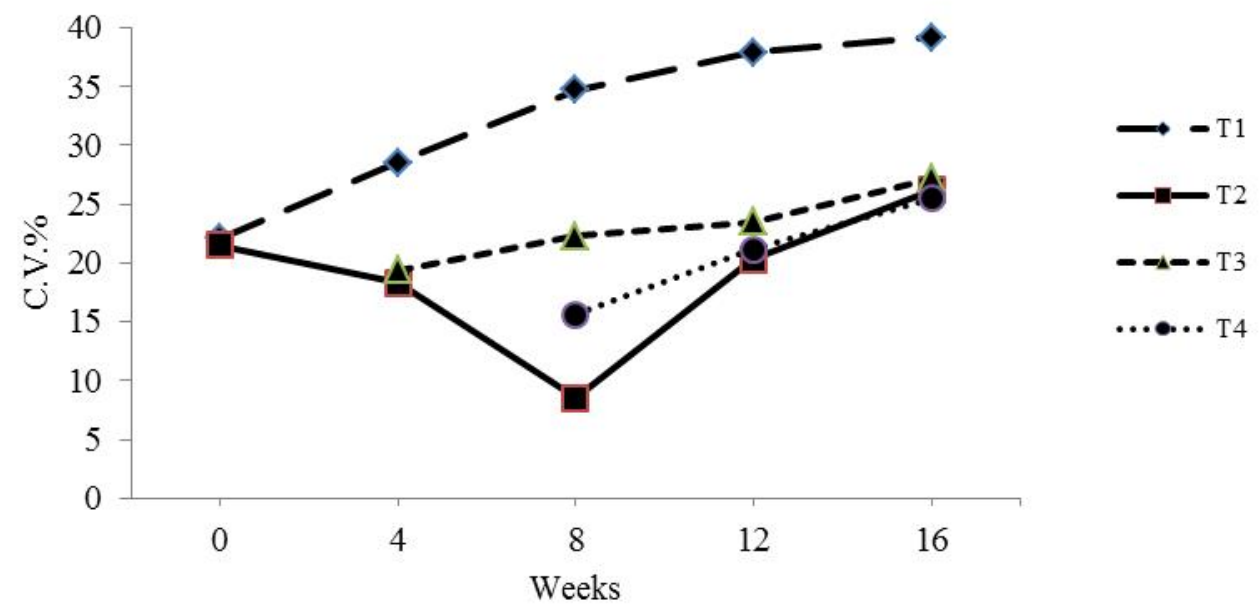

Figure 1. Coefficient of variation C.V.\% for weights of monosex Nile Tilapia fingerlings reared as four experimental groups C: control group; B: base group from which larger fish were removed after $4 \& 8$ weeks; $I_{1}$ : consisted from first isolated larger fish; and $I_{2}$ : consisted from secondary isolated larger fish

As for skewness as measurement of growth variation, the initial size distribution for the control group (C) is negatively skewed and seems to be somewhat symmetric (coefficient of skewness $=-0.3$ ) while the size distribution became progressively positively skewed towards the larger fish with time (coefficient of skewness at the end of the experiment $=1.84)$. Similarly the base population experimental group (B), showed a repeated formation of asymmetric distribution with time. The coefficients of skewness increased in B after the first 4 weeks from- 0.21 to 1.4. Furthermore, regardless that removing of the larger fish after 4 and 8 weeks decreased the coefficients of skewness in (B) to 0.05 and -0.08 respectively it's re-increased to 0.7 at the end of the experiment. As for $I_{1}$, and $I_{2}$ the coefficient of skewness also showed a remarkable increase from $0.42 \& 0.46$ to $1.15 \& 1.22$ at the end of the experiment respectively (Table $2 \&$ Fig.2).

These results indicated that growth depensation was clearly evident in monosex Nile Tilapia fingerlings even if size variability was reduced through removing larger fish and even if groups were consisted with a graded individuals. Some previous studies had been reported a similar aspects of growth depensation between Nile tilapia individuals within the same rearing units in terms of variation in size among individuals and size distributions skewness (Volpato and Fernandes 1994; Volpato et al., 1998; Corrêa et al., 2003 and Barbosoa et al., 2006). The reasons of such variability may be genetically or due to the competition on different resources in the shared environment like food availability (Ryer and Olla, 1996), food quality (Goldan et al., 1998), and space (Huang and Chiu, 1997). Such competitive ability mainly correlated with body size in many fish species including tilapia (Koebele, 1985). As a result of the different competition capabilities according to fish size a hierarchal structure is being formed. The relative position of an individual will determine how it will be able to utilize different shared resources so, some fish grow faster and some other fish will be somewhat suppressed. Such, suppression on the subordinate individuals may be caused with a stress from the behavior of the larger fish or as a result of feeding difficulties or they utilize food energy in evading the dominants rather than for growth. The repeated increase in size variation and the repeated size distribution skewness in all experimental groups indicated the importance of such social source of growth depensation

\section{Growth performance:}

The results (Table 2) revealed that initial body weight (g), final body weight (g), and SGR\% of the experimental groups $\mathrm{C}(0.98 \mathrm{~g}, 4.68 \mathrm{~g}$, and $5.58 \%$ respectively) and $\mathrm{B}(0.97 \mathrm{~g}, 4.56 \mathrm{~g}$, and $5.53 \%$ respectively) didn't differ significantly during the first experimental period (0-4 weeks). During the other experimental periods II, II, and IV the results (Table 2 \& Fig 3) showed that the means of the final body weight of the base experimental group (B) (12.89g.) didn't differ significantly from that of the control group (12.88g.) in spite of the twice removing of the superior growth individuals from it. Additionally, specific growth rates (SGR\%) of the experimental base group B during the experimental periods II, III, and IV were $2.48,1.58$, and $0.72 \%$ respectively which all significantly higher than those of the another three experimental groups. It may be concluded that the removal of larger fish enhances the growth of the remaining individuals in the rearing 
unit. Similar results in other cultured fishes were mentioned by (Wohlfarth, 1977; Wickins, 1987 and Assaf Barki, 2000) who reported an improvement in the growth rate of carp, elevers, and silver perch as a result of the absence of larger fish. Individuals are capable of growing fast in the absence of larger individuals in the same unit. Such improvement may be explained as a compensatory growth as a result of removing the social stress which caused by the larger fish on those smaller ones. The results (Table 2) revealed that the final body weight of $\mathrm{I}_{2}(16.39 \mathrm{~g}$.) and $\mathrm{I}_{1}$ (15.91g.) were significantly $(\mathrm{P}<0.001)$ higher than those of $\mathrm{C}$ and $\mathrm{B}$ experimental groups (12.88 \& 12.89 g. respectively). As both $\mathrm{I}_{1}$ and $\mathrm{I}_{2}$ were formed from the superior growth individuals that isolated from B after 4 \& 8 weeks, respectively, such final superiority after isolation may be explained as those superior individuals have a superior genetic material over the rest of the population.

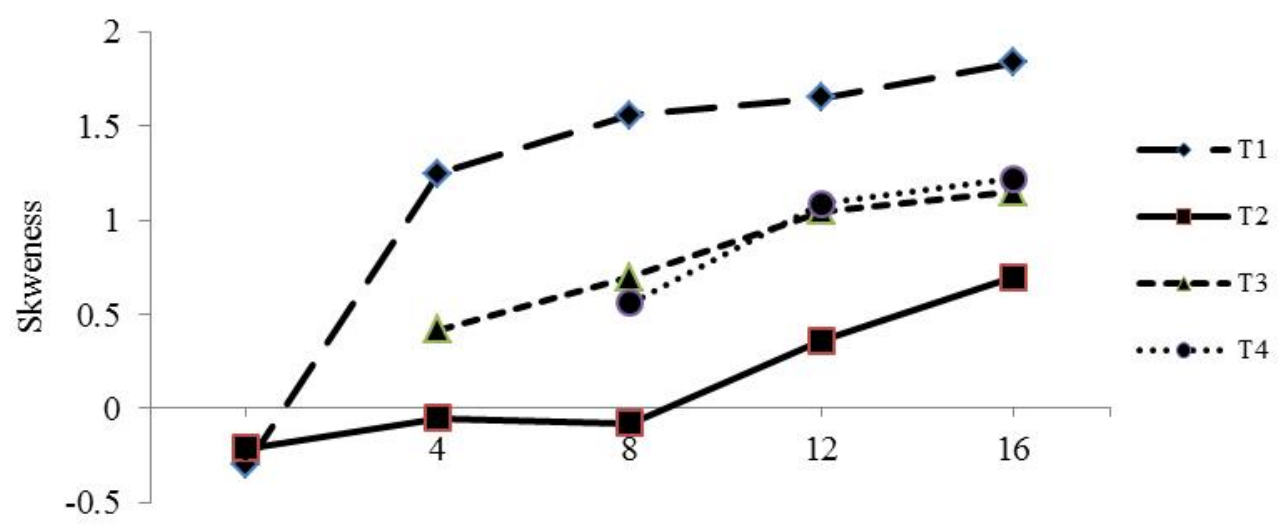

Weeks

Figure 2. Coefficient of skewness for weights of monosex Nile Tilapia fingerlings reared as four experimental groups $\mathrm{C}$ : control group; B: base population from which larger fish were removed after 4 \& 8 weeks; I1: consisted from first isolated larger fish; and I2: consisted from secondary isolated larger fish.

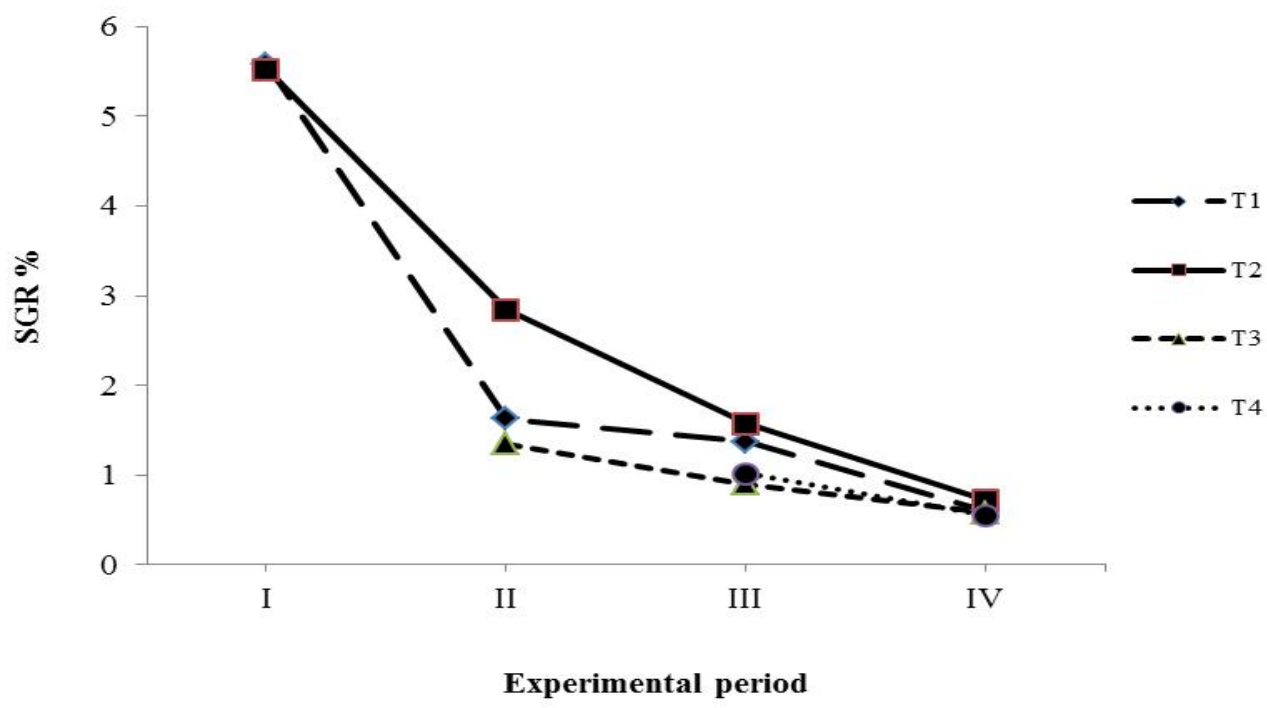

Figure 3. Specific growth rate (SGR \%) for monosex Nile Tilapia fingerlings reared as four experimental groups $C$ : control group; B: base population from which larger fish were removed after 4 \& 8 weeks; I1: consisted from first isolated larger fish; and I2: consisted from secondary isolated larger fish. 


\section{Gene expression study:}

The results of the gene expression study (Fig. 4) indicated that Growth hormone receptor (GHR1) mRNA level was highly up regulated (5.08 folds $\pm 0.98)$ in liver of secondary isolated larger fish $\left(\mathrm{I}_{2}\right)$ than that of the remaining subordinate individuals in the base experimental group B. However, Insulin growth factor-I IGF-I mRNA level was lowly down regulated $(0.76 \pm 0.45)$ in liver of individuals from the experimental group $I_{2}$ than that of the remaining subordinate individuals. Growth hormone $(\mathrm{GH})$ is an important hormone produced by the pituitary gland in teleosts (including Tilapia) as in other vertebrates. $\mathrm{GH}$ acting by binding to a trans-membrane receptor named GH receptor (GHR) in the target tissue (Pérez-Sánchez et al., 2002). GH plays an important role in regulating different physiological processes including growth, metabolism, and osmoregulation (Reinecke et al., 2005). GH also is found to affects several behavioural aspects like appetite, foraging behaviour, aggression, and predator avoidance (Björnsson et al., 2004; and Pérez-Sanchez, 2000). Recent studies have identified two clades of putative receptors for GH (GHR1 clade and GHR2 clade) in fishes both of which are highly expressed in the liver (Jiao et al., 2006; Pierce et al., 2007 \& 2012). The GHR1 has been used as marker for nutritional status and growth preference in fish growth (Perez-Sanchez and Le Bail, 1999; Norbeck et al., 2007) and in the current study, the results of the gene expression experiment (Fig. 4) indicate that growth hormone receptor (GHR1) mRNA level was highly up regulated ( 5.08 folds \pm 0.98$)$ in liver of secondary isolated larger fish group $\left(\mathrm{I}_{2}\right)$ than that of the remaining subordinate individuals. The wide variation of the relative abundance of GHR1 mRNA between $\mathrm{B}$ and $\mathrm{I}_{2}$ (about 5 folds) observed in this study might be explained by the observed variation in fish size between treatments at termination of the study and their relative position in the hierarchal structure within the rearing unit. Dominant individuals within a population have consumed more food and have grown faster than the remaining subordinate individuals. Dominant individuals could chase the remaining subordinate individuals during feeding periods. Many studies showed that liver GH binding is reduced by nutritional restriction (Gray et al., 1992; Pérez-Sanchez et al. 1995 and Deng et al. 2004), suggesting that up regulation of GHR level in the secondary isolated group $\mathrm{I}_{2}$, represented by high GHR1 mRNA level, may be due to their higher relative position in the social hierarchal structure which in turns led to consumption of more food.

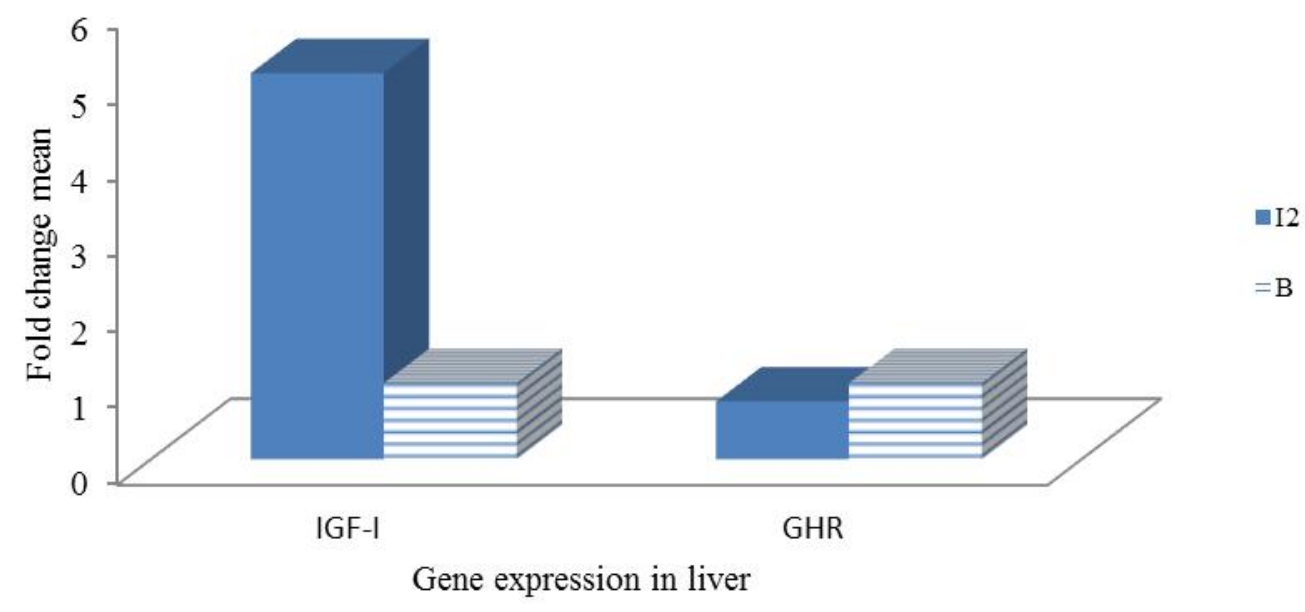

Figure 4. Fold change mean between liver growth hormone receptor (GHR1) mRNA and Insulin growth factor-I IGF-I mRNA of superior growth individuals (I2) and subordinate individuals (B) monosex Nile tilapia fingerlings

\section{CONCLUSION}

The current study led to conclude that, growth depensation phenomena was clearly evident in the monosex Nile tilapia fingerlings. Repeated isolation of the larger fish from the rearing unit may have some advantages in terms of reducing the final size variation and could spare somewhat equal chances for more individuals to grow fast. As for gene expression study, relative position in the hierarchal structure within the same rearing unit effects on the level of GHR1 mRNA.

\section{REFERENCES}

Assaf Barki, H. S., G. Hulata, and I. Karplus, 2000. Effects of larger fish and size grading on growth and size variation in fingerling silver perch. Aquaculture International, 8: 391-401. 
Barbosa J. M., S. S. S Brugiolo, J. Carolsfeld, and S. S. Leitão, 2006. Heterogeneous growth in fingerlings of the Nile Tilapia Oreochromis niloticus: Effects of density and initial size variability. Braz. J. Biol., 66(2A): 537-541

Bjornsson, B.Th., 1997. The biology of salmon growth hormone: from daylight to dominance. Fish Physiol. Biochem. 17, 9-24.

Bzhao, L. Ge, R. Liang, W. Li, K. Ruan, H. Lin, and Y. Jin, 2009. Members of miR-169 family are induced by high salinity and transiently inhibit the NF-YA transcription factor, BMC Mol. Biol. 10 29.

Chambers, R.C., W.C. Leggett and J.A. Brown, 1988. Variation in and among early life history traits of laboratory-reared winter flounder Pseudopleuronectes americanus. Mar. Ecol. Prog. Ser. 47: 1-15.

Corrêa, S.A., M.O. Fernandes, K.K. Iseki, and J.A. Negrão, 2003. Effect of the establishment of dominance relationships on cortisol and other metabolic parameters in Nile tilapia (Oreochromis niloticus). Brazilian Journal of medical and Biological Research 36: 1725-1731.

Davidson, A. E., D. Balciunas, D. Mohn, J. Shaffer, S. Hermanson, S. Sivasubbu, M. P. Cliff, P. B. Hackett, and S. C. Ekker, 2003. Efficient gene delivery and gene expression in zebrafish using the Sleeping Beauty transposon. Dev. Biol. 263, 191-202.

Deng L., W. M. Zhang, H. R. Lin, and C.H. Cheng, 2004. Effects of food deprivation on expression of growth hormone receptor and proximate composition in liver of black seabream Acanthopagrus schlegeli, Comp. Biochem. Physiol. B 137, 421-432.

Duncan, D.B., 1955. Multiple range and multiple F test. Biometrics, 11:1-42.

GAFRD. 2014. General Authority for Fish Resources Development. Annual fishery statistics report, Cairo, Egypt. 96 p.

Goldan, O., D. Popper, and I. Karplus, 1997. Management of size variation in juvenile gilthead sea bream (Sparus aurata). I: particle size and frequency of feeding dry and live food. Aquaculture 152, 181-190.

Goldan, O., D. Popper, S. Kolkovski and I. Karplus, 1998. Management of size variation in juvenile gilthead sea bream (Sparus aurata) II. Dry food type and live/dry food ratio. Aquaculture 165: 313-320.

Gray, E.S., K.M. Kelley, S. Law, R. Tsai, G. Young, and H. A. Bern, 1992. Regulation of hepatic growth hormone receptors in coho salmon (Oncorhynchus kisutch), Gen. Comp. Endocrinol. $88,243-252$.

Hopkins, K. D., 1992. Reporting fish growth: a review of the basics. Journal of the World Aquaculture Society, 23:173-179.

Huang, W.B. and T.S. Chiu, 1997. Effects of stocking density on survival, growth, size variation, and production of Tilapia fry. Aquacult. Res., 28: 165-173

Jiao, B., X. Huang, C.B. Chan, L. Zhang, D. Wang, and C.H. Cheng, 2006. The co-existence of two growth hormone receptors in teleost fish and their differential signal transduction, tissue distribution and hormonal regulation of expression in seabream. Journal of Molecular Endocrinology, 36(1), pp.23-40.

Jobling, M. and B.M. Baarvik, 1994. The influence of environmental manipulations on inter and individual variation in food acquisition and growth performance of Arctic charr, Salvelinus aims. J FM BioL, 44: 1069-1 087.

Kelly, A.M. and D. Heikes, 2013. Sorting and Grading Warm water Fish, Southern Regional Aquaculture Center, Publication, No. 391, University of Arkansas, Pine Bluff, 1:8.

Kinghorn B.P., 1983. A review of quantitative genetics in fish breeding. Aquaculture, 31, pp.283-304.

Koebele, B.P., 1985. Growth and the size hierarchy effect: an experimental assessment of three proposed mechanisms; activity differences, disproportional food acquisition, physiological stress. Environ Biol. Fishes 12(3): 181-188.

Livak, K. J., and T. D. Schmittgen, 2001. Analysis of relative gene expression data using real-time quantitative PCR and the 2(-Delta Delta C(T)) Method. Methods 25:402-408.

Magnuson, J.J., 1962. An analysis of aggressive behavior and competition for food and space in medaka (Oryzim latipes), Pisces, Cyprinodontidae. Cm J. Zool. 40: 3 13-363.

Michael E. S., and A. F. Lee, 2003. Causes of growth depensation in red drum, Sciaenops ocellatus, larvae Environmental Biology of Fishes 66: 4960, 2003.

Norbeck, L.A., J.D. Kittilson, and M.A. Sheridan, 2007. Resolving the growth-promoting and metabolic effects of growth hormone: differential regulation of GH-IGF-I system components. General and comparative endocrinology, 151(3), pp.332-341.

Potthoff, M. T. and M. C. Christman, 2006. Growth depensation and group behavior in juvenile hybrid striped bass Morone chrysops $X$ Morone saxatilis: effects of group membership, feeding method, ration size and size disparity. Journal of Fish Biology 69, 828-845

Perez-Sanchez J. and P.Y.L. Bail, 1999. Growth hormone axis as marker of nutritional status and growth performance in fish. Aquaculture, 177:117-128.

Pérez-Sanchez, J., 2000. The involvement of growth hormone in growth regulation, energy homeostasis and immune function in the gilthead sea bream (Sparus aurata): a short review. Fish Physiol. Biochem. 22, 135-144.

Perez-Sanchez J., H. Marti-Palanca, S.J. Kaushik, 1995. Ration size and protein intake affect circulating growth hormone concentration, 
hepatic growth hormone binding and plasma insulin-like growth factor-I immunoreactivity in a marine teleost, the gilthead sea bream (Sparus aurata), J. Nutr. 125: 546-552.

Pérez-Sanchez, J., J.A. Calduch-Giner, M. Mingarro, S. Vega-Rubnn de Celis, P. Gomez-Requeni, A. Saera-Vila, A. Astola, and M.M. Valdivia, 2002. Overview of fish growth hormone family. New insights in genomic organization and heterogeneity of growth hormone receptors. Fish Physiol. Biochem. 27, 243-258.

Pierce, A.L., J.P. Breves, S. Moriyama, K. Uchida, and E.G. Grau, 2012. Regulation of growth hormone $(\mathrm{GH})$ receptor (GHR1 and GHR2) mRNA level by GH and metabolic hormones in primary cultured tilapia hepatocytes. General and comparative endocrinology, 179 (1), 22-29.

Pierce, A.L., B.K. Fox, L.K. Davis, N. Visitacion, T. Kitahashi, T. Hirano, and E.G. Grau, 2007. Prolactin receptor, growth hormone receptor, and putative somatolactin receptor in Mozambique tilapia: tissue specific expression and differential regulation by salinity and fasting. General and comparative endocrinology, 154(1), 31:40.

Ra'rnan, Z., and D. Cohen, 1984. The effect of group interactions on the development of size distribution in Mach brachiurn rosenbergii (De Man) juvenile populations. Bio. Z. Bull. 166, 22:3.
Reinecke, M., T. B. Bjorn, W. D. Walton, D. M. Stephen, N. Isabel, M. P. Deborah, and G. Joaquim, 2005. Growth hormone and insulin-like growth factors in fish: Where we are and where to go. General and Comparative Endocrinology 142 (2005) 20-24

Ryer, C.H. and B.L. Olla, 1996. Growth depensation and aggression in laboratory reared coho salmon: The effect of food distribution and ration size. J. Fish Biol. 48: 686-694.

SPSS., 2013. IBM Corp. Released 2013. IBM SPSS Statistics for Windows, Version 22.0. Armonk, NY: IBM Corp.

Sudhindra R. G., 1997. Social behavior and growth variation in cultured tilapia Oreochromius niloticus .Ph. D. thesis, Dalhousie University, Halifax, Nova Scotia.

Volpato G.L. and M. O. Fernandes, 1994. Social control growth in fish. Brazilian Journal of Medical and Biological Research, 27: 797-810.

Volpato G.L.., P. M. A. Frioli, and M. P. Carrieri, 1998. Heterogeneous growth in fishes: some new data of Nile tilapia Oreochromis niloticus and a general view about the causal mechanisms. Bol. Fisiol. An. São Paulo, 13: 7-22.

Wickins, J.F., 1987. Effects of size, culling and social history on growth of cultured elvers, Anguilla angtcizia (L.). J. Fish Biol., 31: 71 -82.

Wohlfarth, G.W., 1977. Shoot carp. Bamidgeh. 29(2): 35-56.

\footnotetext{
إختبار مسببات تفاوت النمو فى أصبعيات البلطى النيلى وحيد الجنس

محمد محمد سعيد، ايمـان عبد الله منـاع

1 ـ قسم الإستزراع المائس، كلية الثروة السمكية، جامعه السويس، السويس، مصر، + ـ قسم تنمبه الثروة الحيوانية، كلية الطب البيطرى، جامعة

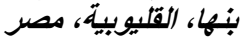

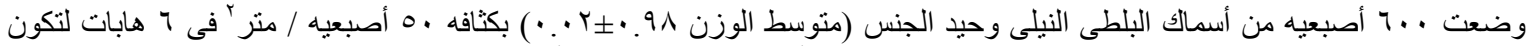

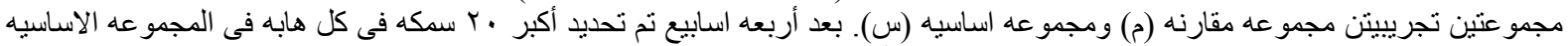

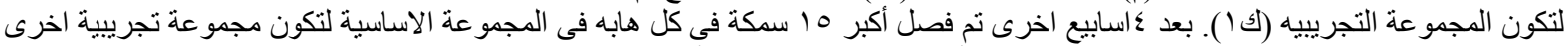

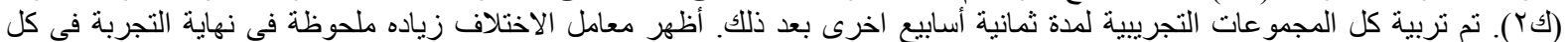

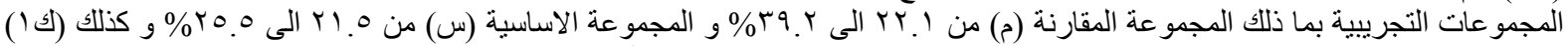

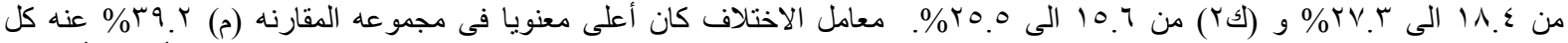

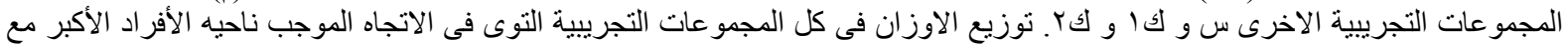

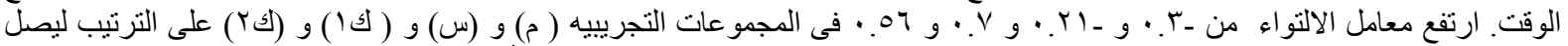

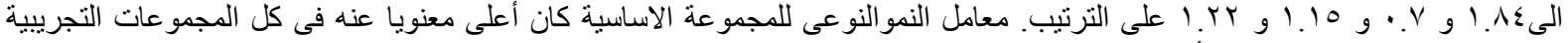

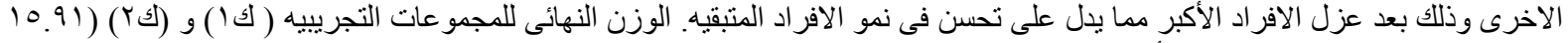

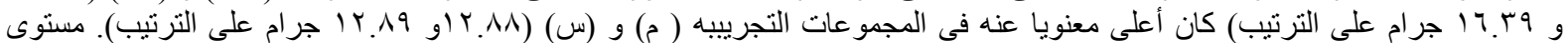

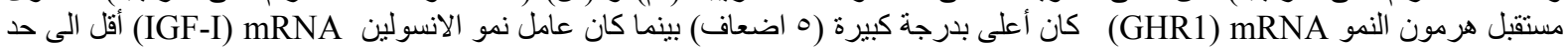

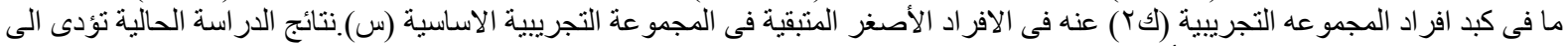

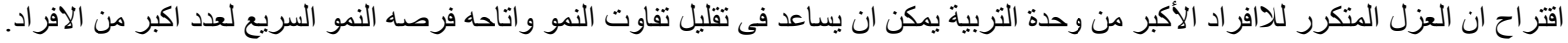

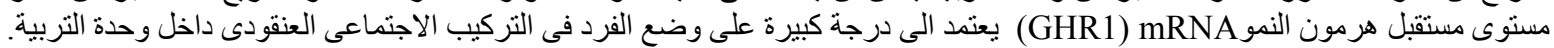

